\title{
COMPETITIVENESS OF LEADING COMMODITIES TO SUPPORT DEVELOPING REGION OF AGROTOURISM
}

\author{
Murwatiningsih \\ Faculty of Economics, Universitas Negeri Semarang \\ e-mail: murwatiningsih_fe@yahoo.com \\ Dyah Maya Nihayah \\ Faculty of Economics, Universitas Negeri Semarang \\ Shanty Oktavilia \\ Faculty of Economics, Universitas Negeri Semarang
}

\begin{abstract}
The aim of the research is to seek the competitiveness of the leading commodity in Semarang city which supports the development of centre commodity in agrotourism area. The method of analysis is leading sector, scoring analysis and capacity asessment through FGD. The result of the research reveals that leading commodities are Durian, Longan, Water Apple, and Rambutan. It is found that subdistrict Gunungpati and Mangunsari are ready to be the centre of horticulture commodity because its strategic location. It is located nearby Jatibarang reservoir (potential to be a tourism village), its cultivation is relatively successful, accessable transportation, and good management. Hence, it can be the pilot project area.
\end{abstract}

Key words: competitiveness, centre, commodity, horticulture

JEL Classification: O20, Q10

DOI: http://dx.doi.org/10.20885/ejem.vol5.iss2.art6

\begin{abstract}
Abstrak
Kesejahteraan petani tidak meningkat karena daya saingnya rendah dan pengelolannya tidak optimal. Tujuan penelitian, untuk melihat daya saing komoditas unggulan Kota Semarang untuk mendukung pengembangan sentra komoditas di kawasan agrowisata. Metode analisis yaitu sektor basis, analisis scoring serta capacity assessment melalui FGD. Hasil penelitian menunjukkan komoditas yang diunggulkan di Gunungpati adalah durian, klengkeng, jambu air dan rambutan. Kelurahan Gunungpati dan Mangunsari siap dijadikan sentra komoditas hortikultura di Kecamatan Gunungpati karena letaknya strategis- dekat dengan waduk Jatibarang (dapat menjadi desa wisata), budidaya relatif lebih berhasil, transportasi dan akseptibilitas lebih mudah, pengelolaannya bagus sehingga sudah menjadi daerah percontohan.
\end{abstract}

Kata Kunci: daya saing, sentra, komoditas, hortikultur JEL Classification: O20, Q10

\section{INTRODUCTION}

Consumption of horticultural products has been increasing along with the increasing awareness of healthy life syle. It can be seen from theincrease of consumption on fruits and vegetables. Directorate General of Indonesia Horticulture (2009) reveales that Indonesian fruits consumption reaches as much as 12.656.031 tons in 2003 until 2009. This condition shows there are great potentials for horticultural business to develop. Irawan (2003) states that the opportunities and challenges of agribusiness will 
rise continously. Indonesia has imported fruits as much 692.703 tons in 2010. This number has increased to 832.080 in 2011 (Directorate of Horticulture, 2012). Meanwhile, in 2013, import of horticultural products reach 1.6 billion US dollars. This high import indicates a problem on food sovereignity. Actually, the concept of food sovereignty is more important and strategic than concept of self-sufficiency and food security (Arifin, 2013).

In fact, Indonesia still has potential horticultural commodities that can be further developed. It has been confirmedin theprevious studies conducted by Muslim (2006 ), Hagi et al (2012), Nihayah (2011), as well as Suprihatini (2005) who reveal that many agro-products and horticultural commodities have comparative and competitive advantages that can compete with other productsin the global market. However, the characteristics of horticultural commodities are found to be easily damaged, and shrinking rapidly. These become critical problems faced by farmers and traders. Ultimately, this condition has led to physical and price risk for horticulture and agribusiness causing disruption of demand and supply.

Subdistrict Gunungpati is a green belt area of Semarang as a guard against land conversion. Government of Semarang City has established Gunungpati District as an agrotourism area. It was mentioned in the Spatial and Layout Plan of Semarang at 2000-2010. Various types of horticultural have been cultivated in this region. The elements mentioned in the plansuch as efficiency, productivity, and quality, should be considered as priorities in order to meet market demand and consumer preferences (Murwatiningsih (2009) and Nihayah (2012)).

Horticultural cultivation is one of the Conservation Programs in Higher Area of Semarang and Poverty Alleviation ( PKLSAPK-in Indonesian it stands for Pogram Konservasi Pengentasan Kemiskinan Lahan Semarang Atas dan Pengentasan
Kemiskinan) to address critical land in Gunungpati Subdistrict. The program aims to create a comprehensive system starting from harvest management to product marketing in ensuring the product values improvement. It is expected that by improving the values of the products, the income of the farmers will also increase. Then, it will decrease poverty in the area (Watanabe, et al, 2009).

The study related to the establishment of horticulture centre in Gunungpati has been first started by mapping the horticulture economic potentials conducted by Margunani et al. (2012). The study reveals that the land structure and contour influencing the spread of horticulture commoditiesin Gunungpati. The types of horticulture which are mostly cultivated are fruits such as Durian, Rambutan, Jack Fruit, and water apple. The others which include vegetables are long.

Managing institution and developing agribusiness centre have become priorities in the establishment of agrotourism (Margunani, et al, 2012).Through the management of institution, the chain of commodity, market, territorial, and the policy review can be created (Mather, 1999). Agribusiness integrity is beneficial to improve the added value of the horticulture products bybetter processing to make themmore economical. Besides, research and development $(R \& D)$ is significantly required to find food varieties from the produce which can be created and developed.

This can be realized by empowering women and young generations who are reluctant in working on this sector. Saptana et al (2004) and Patrick (2004) clarify that existence of institution and agribusiness intergrity will create mutual cooperations. It is expected that related stakeholders will collaboratively control over the quality standard to meet the need of consumers. This paper is aimed to see one of the leading commodities in Semarang to support the commodity centre development in agrotourism. 


\section{METHODS}

Primary and secondary data are used in this study. The population is horticulture farmers in Gunungpati subdistrict. The sample employs technique of stratified sampling. It means that farmers are grouped into stratum based on their location (village). This is due to the differences are driven by its location leading to various structures and characteristics.

This research uses quantitative and qualitative description techniques. Descriptive analysis means that the process of the problem solving and the condition of the subject and the object of the research are described based on the existing facts. Prajanti (2010) uses triangulation to conceptualize the use of mix method. The method is the quantitative as the primary method, and the qualitative is used to describe the data. To answer the question of the research, there are steps which have been conducted. The first step is deciding the leading commodities. This is executed by using the LQ and Shift Shareanalysis technique.

LQ analysis can be used to find out whether certain sectors are potential to export or not (whether the sectors can meet the need of their own regions or other regions). The formula is:

$$
L Q=\frac{S_{i r} / S_{r}}{S_{i n} / S_{n}}
$$

Where

$S_{i r}$ is the value of commodity $\mathrm{i}$ in region $r$

$S_{r}$ is the value of commodity production $\mathrm{i}$ in region $r$

$S_{i n}$ is the dded value of commodity $i$ natioally

$S_{n}$ is value of commodity production $i$ nationally.

The use of LQ as a way to find comparative advantage can be used for sectors which have been developed. Meanwhile, the use of LQ for new sectors or developing sectors are never applied.

To compare the difference of industrial sector growth inthe district with the province or province with the national territory, Shift Share analysis is employed. This method provides details of the factors which cause changes in the industrial structure of a region during its growth over time. Shift Component is the deviation of the national share of regional employment growth. This deviation is positive in areas that develop faster, and it is negative in areas that develop slower compared to the national employment growth. For each net shift area, it can be divided into two: shifts proportional component and shift differential component.

Proportional shift component is sometimes known as structural components or industrial mix. This component ispositivein areas specializing in sectors which nationally develop rapidly and it is negative in areas specializing in sectors which nationally develop slowly or even in a declining condition. Differential shift component is also called regional locational component. It is the remaining excess. This component measures the amount of net regional shift which is caused by certain industrial sectors which develop faster or slower in the region rather than at the national level caused by internal locational factors. Therefore, a region which has location advantage such as abundant resources/ efficient will have positive differential component. And, the region which has no location advantage will have a negative differential component. This shift component seperates two elements of regional growth influenced by external elements at the national level. Meanwhile, differential shift is a result from the influence of its region internal factor.

The second step is identifying the internal and external environment of the leading commodities. The environment analysis is conducted by using scoring method. The environment analysis is ap- 
plied in the centre of commodity. The scoring method is used due toempirically the suply chain management systems principles are not yet applied well by the businesmen. Some are reflected by (1) there are not fully oriented to meet the need of the consumers; (2) the marketing system is not effective and efficient yet; (3) there is a limit on the use of production infrastructure and distributon of horticulture products; and (4) The weakness of the management information and its transparency.

The third step is to get appropriate empirical data, the result from the first and second steps are reviewed and checked by employing focus group discussion (FGD) involving horticulture stakeholders (farmers, association, and government officers). Participative method is employed in this step.

\section{RESULT AND DISCUSSION}

The respondents of the research are the chief of the farmer group in Gunungpati subdistrict that is involved in the Program of Land Conservation in Higher area of Semarang and Poverty Alleviation (PKLSAPK). This progam is supported by Japanese Government grant of Japan Social Development Fund (JSDF). The area which is used reaching 2 ha to 3.5 ha (Figure 1).

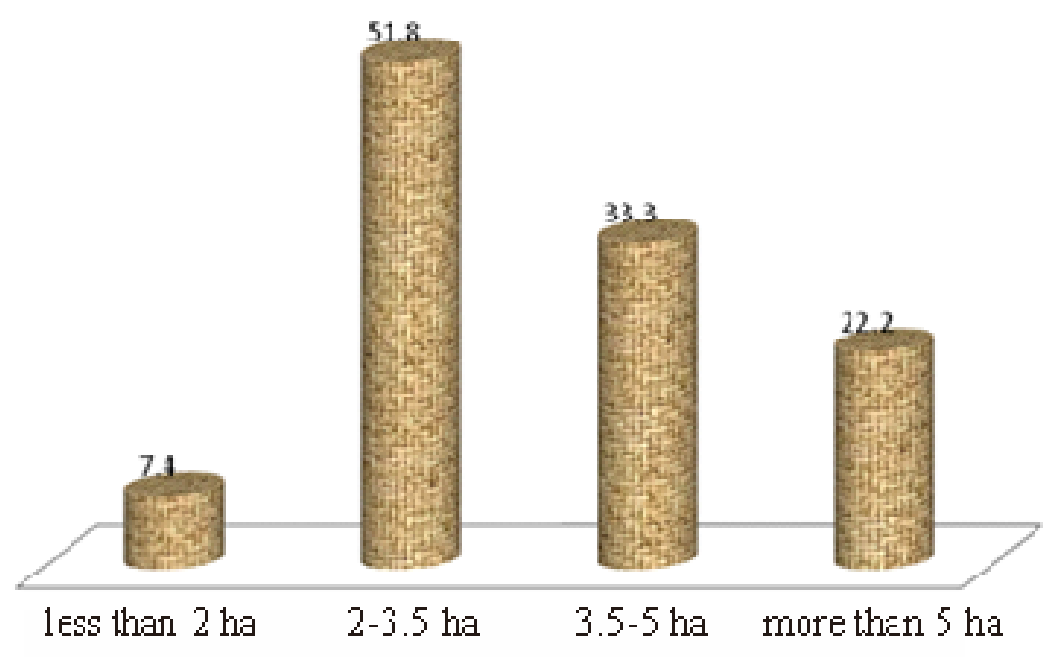

Figure 1: Land Ownership by Farmer Group JSDF (in \%)

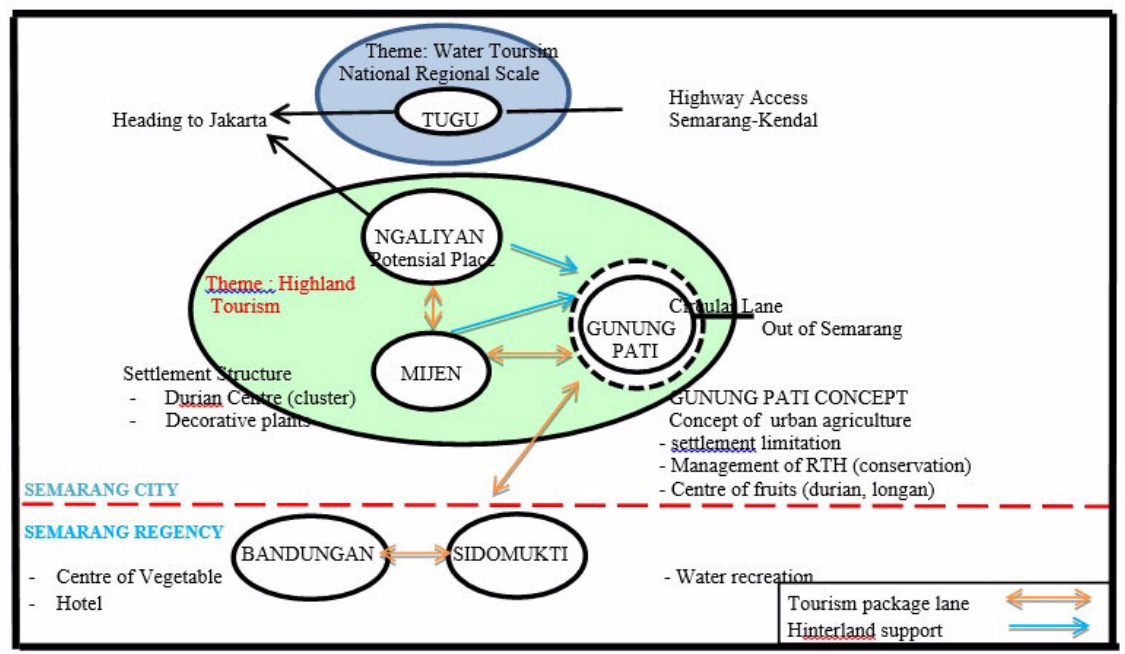

Figure 2: Map of Agrotourism in Semarang City 
Eventhough the land is bent due to the JSDF program, however, such condition implies that existing condition of the land does not become the main barriers to cultivate. This shows a positive impact in improving the welfare of the farmers if it is efficiently managed. The bent land in Gunungpati area which is funded has 100.14 ha width.

The determination of Gunungapti as Agrotourism is the continuation of the existing regional regulation of Semarang City number 12004 on Spatial Planning (RTRW) Semarang city 2000-2010. It states that the agrotourism is in BWK VI (Tembalang dubsitrict), BWK VIII (Gunungpati subdistrict), and BWK IX (Mijen subdistrict) which also functions as the centre of research and development of agriculture and cultivation. The map of the agrotourism is in Figure 2.

\section{The Selection of LeadingCommodities}

This step aims to determine the basic sector using LQ analysis. Basically, the economic sector is divided into two big sectors- basic and non-basic sectors. Basic sector is sector which is able to meet the need of its internal market in the region. The basic sector can export the products and services outside the region. Meanwhile, the non-basic sector can meet the need of its internal market in the region but the import activitesstill exist.

Semarang city, like the other city, has its sectoral charcteristics which is dif- ferent from its village. It can be seen from its contribution rate on agriculture which is $1.12 \%$ a year with its declining trend in the period of 2009-2011 (Table 1).

The role of the agricultural sector for economy in Semarang city is also demonstrated by the ability of the agricultural sector as a basic sector in the regional economy. Location Quotient (LQ) is used to determine basic sector (basic economy) or the potential goods to export and the non-basic sector.

Table 1 shows basic sectors including construction, transportation and communications, electricity, gas, and water supply, trade, hotels, and restaurants, as well as the service sector.

The five sectors have consistently become basic sectors that have comparative advantage within three years. This is based on the calculation of LQ which is more than 1 (LQ > 1). The agricultural sector has $\mathrm{LQ}<1$. It means this sector is not the basic sector in Semarang City (Table 2).

However, the non-basic sector does not necessarily have no competitive advantage in the market. It is expected that the output of each economic sector does not only have comparative advantage, but also competitive one. Competitive advantage is the ability of each region in maximazing its potential to compete with its competitiors. Table 3 is the competitive advantage based on the $\mathrm{Cij}$ value.

Table1: The Contribution of Economic Sector towards Total PDRB of Semarang City (\%).

\begin{tabular}{lrrrr}
\hline \multicolumn{1}{c}{ Sector } & $\mathbf{2 0 0 9}$ & $\mathbf{2 0 1 0}$ & $\mathbf{2 0 1 1}$ & Average \\
\hline 1.Agriculture & 1.16 & 1.13 & 1.08 & 1.12 \\
2.Mining andquarrying & 0.16 & 0.15 & 0.15 & 0.15 \\
3.manufacturing & 27.08 & 26.83 & 26.60 & 26.84 \\
4.Electricity gas, and clean water & 1.29 & 1.27 & 1.25 & 1.27 \\
5.Construction & 15.27 & 15.45 & 15.55 & 15.42 \\
6. Trading, hotel \& restaurant & 30.81 & 30.83 & 30.90 & 30.85 \\
7.Transportation and communication & 9.67 & 9.67 & 9.64 & 9.66 \\
8.Finance, leasing, and company service. & 2.80 & 2.73 & 2.71 & 2.75 \\
9.services & 11.76 & 11.94 & 12.13 & 11.94 \\
\hline
\end{tabular}

Source: Semarang City in Numbers, 2012, processed. 
Table 2: Analysis of LQ Sector in Semarang City

\begin{tabular}{lcccc}
\hline Field & $\mathbf{2 0 0 9}$ & $\mathbf{2 0 1 0}$ & $\mathbf{2 0 1 1}$ & Average \\
\hline Agriculture & 0,06 & 0,08 & 0,06 & 0,07 \\
Miningand quarrying & 0,14 & 0,13 & 0,13 & 0,13 \\
Manufacture & 0,83 & 0,77 & 0,80 & 0,80 \\
Electricity, gas, and clean water & 1,53 & 1,39 & 1,47 & 1,46 \\
Construction & 2,62 & 2,48 & 2,63 & 2,58 \\
Trade, hotel, \&Restaurant & 1,44 & 1,36 & 1,42 & 1,41 \\
Transportation and communication & 1,86 & 1,75 & 1,80 & 1,80 \\
Finance, leasing, and company service & 0,74 & 0,69 & 0,72 & 0,71 \\
Services & 1,17 & 1,11 & 1,18 & 1,15 \\
\hline
\end{tabular}

Source: Semarang City in Numbers, 2012, processed

Table 3: Competitive Advantage based on CIJ Value in Shift Analysis of Semarang City.

\begin{tabular}{lr}
\hline Field & Average \\
\hline Agriculture & $162,710.01$ \\
Miningand quarrying & $-224,024.71$ \\
Manufacture & $-18,635,424.94$ \\
Electricity, gas, and clean water & $-1,022,264.64$ \\
Construction & $3,103,047.16$ \\
Trade, hotel, \&Restaurant & $-6,531,645.97$ \\
Transportation and communication & $-6,863,307.11$ \\
Finance, leasing, and company service & $-1,718,727.42$ \\
Services & $1,799,379.92$ \\
\hline
\end{tabular}

Source: Semarang City in Numbers, 2012, processed.

The positive value in a sector indicates better level of competitiveness compared to the other sectors. If a sector has negative $\mathrm{Cij}$, it indicates that the commodity has declining competitiveness level. In 2009-2011, the sectors which have competitive advantage in Semarang city are agriculture, construction, and services. Eventhough agricultural sector does not have comparative advantage, it has competitive advantage. Meanwhile, construction and service sectors have both comparative and competitive advantage.

There are many sectors which are included as basic sectors potential to be developed in increasing the growth and economic development in Semarang city. However, the other non-basic sectors such as agricultural sector, mining and quarrying, manufacturing, financing, leasing, and service sectors cannot be neglected. This is due to these sectors are also potential to be developed as basic sectors in Semarang City.

\section{Analysis of Fruit Horticultural Com- modities Advantage}

In the City of Semarang, agricultural sector can be seen by its productions in a number of agricultural centers such as in the District of Gunungpati, Mijen, and Semarang Barat (West Semarang). Especially for horticultural fruit crops, production of fruit commodities in Gunung Pati describes fruit productivity of the city. Comparative and competitive advantage analysis of fruit commodities in Gunungpati is represented by data of fruit commodities in the city.

Sectorally, although agriculture has a low LQ value, in the period of 2009-2011 the value increased 0.02 level. If the development of productivity is consistently kept stable, agricultural sector in Semarang City could contribute better in the following years. This can be seen using LQ analysis based on production value of fruit commodities in Semarang City. 
Table 4.LQ Analysis of Fruit Commodities of Semarang City

\begin{tabular}{clcccc}
\hline No & Commodities & $\mathbf{2 0 0 9}$ & $\mathbf{2 0 1 0}$ & $\mathbf{2 0 1 1}$ & Average \\
\hline 1 & Rambutan & 4.29 & 1.04 & 6.43 & 3.92 \\
2 & Longan & 1.28 & 4.70 & 4.00 & 3.33 \\
3 & Jackfruit & 8.56 & 0.47 & 0.04 & 3.02 \\
4 & Durian & 2.13 & 0.42 & 2.09 & 1.55 \\
5 & Banana & 0.50 & 1.55 & 1.37 & 1.14 \\
6 & Mangosteen & 3.00 & 0.06 & 0.21 & 1.09 \\
7 & Soursop & 2.14 & 0.98 & 0.14 & 1.09 \\
8 & Water apple & 1.77 & 1.02 & 0.14 & 0.98 \\
9 & Sapodilla & 1.71 & 0.19 & 0.05 & 0.65 \\
10 & Petai & 0.89 & 0.75 & 0.12 & 0.59 \\
11 & Mango & 0.39 & 0.79 & 0.47 & 0.55 \\
12 & Breadfruit & 0.33 & 0.73 & 0.35 & 0.47 \\
13 & Star fruit & 0.48 & 0.56 & 0.23 & 0.42 \\
14 & Papaya & 0.10 & 0.37 & 0.14 & 0.20 \\
15 & Guava & 0.17 & 0.20 & 0.07 & 0.15 \\
16 & Duku & 0.01 & 0.01 & 0.24 & 0.09 \\
17 & Jengkol & 0.01 & 0.18 & 0.05 & 0.08 \\
18 & Melinjo & 0.02 & 0.09 & 0.02 & 0.04 \\
19 & Pineaple & 0.05 & 0.03 & 0.01 & 0.03 \\
20 & Jeruk besar (Grape fruit) & 0.00 & 0.01 & 0.03 & 0.01 \\
21 & Salacca & 0.02 & 0.01 & 0.00 & 0.01 \\
22 & Tangerine & 0.00 & 0.03 & 0.00 & 0.01 \\
23 & Avocado & 0.01 & 0.01 & 0.01 & 0.01 \\
\hline Source Agriculturat Office
\end{tabular}

Source: Agricultural Office of Semarang City, processed

Table 4 shows fruit crops which are potential to be developed and to be basic commodities in Semarang City. Fruit commodities potential to be grown are water apple, sapodilla, and mango. Meanwhile, the fruits that can potentially be the basic commodities are rambutan, longan, jackfruit, durian, banana, mangosteen, and soursop.

However, fruit commodities having comparative advantage are unnecessarily having competitive one. Competitive advantage which is represented by $\mathrm{Cij}$ value can be measured using shift share analysis. Positive $\mathrm{Cij}$ value suggests that a commodity has competitive advantage and negative $\mathrm{Cij}$ value means that a commodity has no competitive value.

In Semarang City, fruit commoditis having competitive advantage are ra mbutan, banana, durian, mango, longan, mangosteen, duku, breadfruit, grape fruit (jeruk besar), avocado, and star fruit. (Table 5).

Commodities having competitiveness are those having comparative and competitive advantage. The competitiveness is reflected from LQ values of $>1$ and positive shift share values. Therefore, based on LQ analysis (table 4) and shiftshare analysis (table 5), fruit commodities in Semarang City which have competitiveness are rambutan, durian, longan, banana, and mangosteen.

Environment analysis for competitive commodity development is analyzed by using scoring analysis. The procedure of scoring analysis is easier, simpler, and more practical. Determining special quality commodities is based on certain indicators where each of which is comprised of some criteria. Each criterion is scored in order to list its priority of development. 
Table 5: Competitive Advantage Value (Cij)

Fruit Commodities of Semarang City by ShifShare Analysis

\begin{tabular}{clc}
\hline No & Commodities & Competitive Advantage Value $(\mathbf{C i j})$ \\
\hline 1 & Rambutan & 15666978.89 \\
2 & Banana & 11386910.9 \\
3 & Durian & 3023480.988 \\
4 & Mango & 1080692.18 \\
5 & Longan & 35688 \\
6 & Mangosteen & 21665.43346 \\
7 & Duku & 20314.25543 \\
8 & Breadfruit & 16027.11829 \\
9 & Grape fruit & 2385.908963 \\
10 & Avocado & 812.1502654 \\
11 & Star fruit & 67.62292508 \\
12 & Jengkol & -3403.811525 \\
13 & Tangerine & -4449.960066 \\
14 & Sapodilla & -4482.080571 \\
15 & Papaya & -8472.816963 \\
16 & Guava & -8620.300907 \\
17 & Salacca & -10594.08626 \\
18 & Melinjo & -13416.65153 \\
19 & Pineapple & -16428.31243 \\
20 & Soursop & -20429.01997 \\
21 & Water apple & -87904.6589 \\
22 & Petai & -182716.7961 \\
23 & Jackfruit & -272202.5976 \\
\hline
\end{tabular}

Source: Agricultural Office of Semarang City, processed

There are three indicators measured. They are 1) cultivation development; 2) postharvest \& marketing; and 3) availability of facilities and supporting infrastructure. The criteria used refer to its strengths and weaknesses and opportunities and threats faced by horticultural commodities. The weights of assessment are 1: very bad, 2: bad, 3: good, 4: very good, result of scoring.

Scoring analysis is used in four commodities which are developed in the District of Gunungpati in order to support it as agro-industrial area. Those three commodities are durian, longan, rambutan, and water apple. Based on LQ and shift share analysis, water apple is the commodity which has comparative advantage but does not have competitive advantage. Scoring analysis is also usedin this commodity because starting from 2012 water apple crops are widely cultivated as "tanaman tunggu" (a commodity which is cultivated while waiting for other commodities to harvest due to time constraint) for basic crops at JSDF program (durian) which takes long time to harvest.

\section{Cultivation development}

For the indicator of cultivation development, there are 7 criteria measured (Table 6). By this indicator, longan commodity has the strength at land preparation, human resources (number and skill), provision of seeds and farm tools, and current quality of fruits and vegetables (table 6).

Longan is widely grown due to its easy and economical cultivation as well as its high price. Rambutan has the strength at how to harvest and easy fertilization (table 6). Say, it can grow by itself and plenty rambutan fruits can be harvested. However, the price is low. Even in the harvest time, the price merely ranges between Rp. 1.500 andRp. 3.000 for certain types of rambutan. 
Table 6: Cultivation Development Leading Commodity in the District of Gunungpati

\begin{tabular}{clcccc}
\hline No & \multicolumn{1}{c}{ Criteria } & Durian & Longan & Rambutan & Water apple \\
\hline 1 & Land preparation & 2,3 & 2,5 & 2,3 & 2,4 \\
2 & Human resources (number\&skill) & 2,2 & 2,4 & 1,9 & 2,4 \\
3 & Provision of seeds and farm tools & 3,0 & 3,1 & 3,0 & 2,9 \\
4 & Current quality of fruits and vegetables & 2,1 & 2,3 & 2,2 & 2,2 \\
5 & Technical and cultivation development & 2,5 & 2,6 & 2,5 & 2,7 \\
6 & How to harvest & 2,3 & 2,4 & 2,7 & 2,2 \\
7 & Fertilization & 2,3 & 2,1 & 2,6 & 2,0 \\
\hline
\end{tabular}

Source: Primary Data

Durian commodity which belongs to basic crop since its first cultivation, either local or - due to JFDF program known as durian monti or durian montong Gunungpati has worse indicator of cultivation than longan, rambutan, and water apple (table 6). Based on FGD, it is revealed that many durian crops of JFDF program die during their growth. This has enforced farmers to replace their crops with longan or water apple (avocado, in Sumurejo area). This condition has caused different life span of durian crops.

Local durian is plenty in its quantity or availability. Each house grows 1 to 5 local durian trees. When the weather is supporting (low intensity of rainfall and wind), 1 durian tree can produce approximately 100 $\mathrm{Kg}$ of durian. Local durian has fewer problems that monti durian. This is because the three has lived for decades. Crop failure of local durian is usually caused by the weather. Whereas the death of monti durian is usually caused by lack of water and stem cancer. Meanwhile, for longan and water apples, provision of seeds is crucial because the main problem is the quantity of the product. So far, farmers in Gunungpati have not been able to fulfill market demand.

In order to support agricultural business activities especially the program for developing leading fruit commodities in the District of Gunungpati, local Agricultural Office has attempted to do nursery. Several commodities that have been nursed are as many as 5000 seeds of jambu Kristal, a number of durian seeds, and some longan (klengkeng itoh and diamond river). Agricultural
Office of the District of Gunungpati has cultivated 600 trees of Jambu Kristal, 1500 trees of longan, 322 trees of durian, 63 trees of water apple, 130 trees of Srikaya Gugus, and 177 trees of honey soursop (sirsak madu). Diamond river longan is not really good since it is quite juicy. Soursop commodity grown in the district is honey soursop. The seeds are quite good in marketing.

\section{Postharvest and marketing}

In postharvest and marketing, it can be seen that rambutan commodity is the best among others. Its average is higher than the others. (Table 7).

Longan has been sorted in order to select and separate superior quality from ordinary one based on its size. For marketing, the price, and market share, durian ranks first. This strengthens basic sectoral analysis showing that durian commodity has good competitiveness in Semarang City.

Marketing of most horticultural fruits in the District of Gunungpati does not use service of any marketing institutions so as to channel the commodity to consumers. The reason is that the farmers want to be efficient. Marketing analysis is obtained by paying attention to each channel of commodity marketing in the research area.

Commodity marketing in the research area is carried out in three choices of channels (Figure 3). First, respondents sell their own products directly to consumers. This is done by selling the products in their own stands. In this case, farmers act as sellers. Based on interviews with the farmers, they do it because it is easier and more efficient. 
Table 7: Postharvestand MarketingLeading commodity in the District of Gunungpati

\begin{tabular}{clcccc}
\hline No & \multicolumn{1}{c}{ Criteria } & Durian & Longan & Rambutan & Water apple \\
\hline 1 & How to harvest & 2,4 & 2,4 & 2,8 & 2,2 \\
2 & Harvesting tools & 2,3 & 2,2 & 2,5 & 2,0 \\
3 & Product sorting & 2,2 & 2,4 & 1,7 & 2,2 \\
4 & Packaging tools & 1,0 & 1,0 & 1,2 & 0,9 \\
5 & Storehouse & 1,0 & 1,0 & 1,2 & 0,9 \\
6 & Place for sale & 2,1 & 2,0 & 2,5 & 1,9 \\
7 & Transportation to the place for sale & 2,5 & 2,5 & 2,8 & 2,1 \\
8 & Price of the product & 2,9 & 2,9 & 2,0 & 2,7 \\
9 & Market share & 3,1 & 3,1 & 1,4 & 2,8 \\
\hline
\end{tabular}

Source: Primary Data

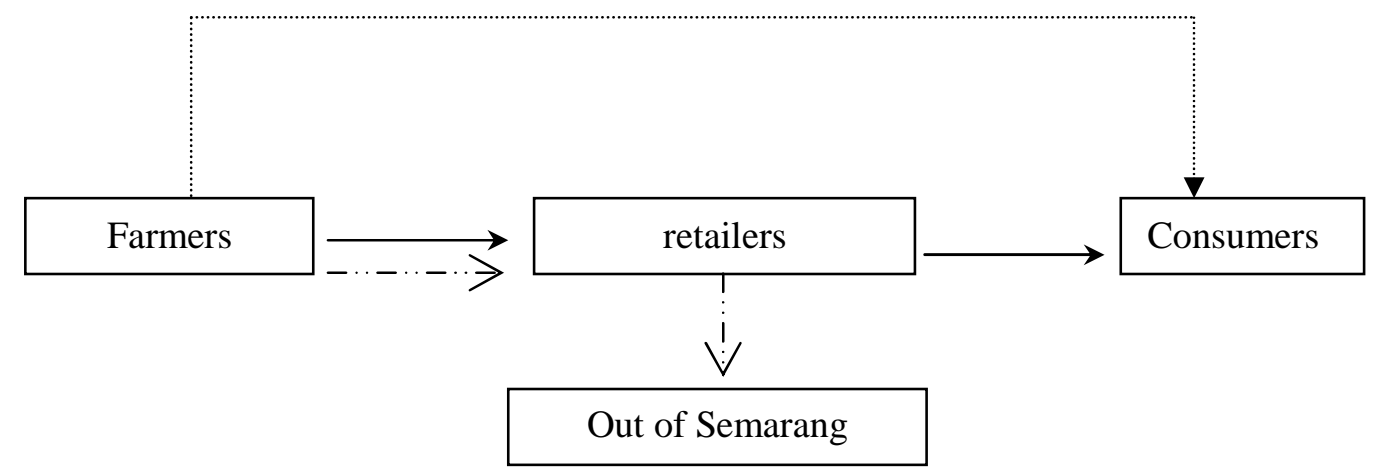

Note:

$\rightarrow$ channel 1

channel 2

$-\cdots \rightarrow$ channel 3

Figure 3: Marketing Channel

Horticultural Fruit Commodities in the District of Gunungpati

Another consideration of the farmers is thatthey can determine the price if they themselves sell the products. The second way is the farmers sell the commodities through resellers. Resellers will come directly to the farmers, taking the commodities, and sell them in stands. Consumers buy the fruitsfrom those stands. The third way is that the farmers sell their products to other regions (out of Semarang City) through resellers.

\section{Availability of facility and supporting ac- tivities}

Availability of facility and supporting activitiesshould be integrated with cultivation of horticultural crops in realizing the Dis- trict of Gunungpati as agricultural city of tourism in the City of Semarang. However, basic infrastructures have not been built properly. There is no excuse, basic infrastructure should be builtin order to support the program. Currently, the value ranges only between 1, 8 (bad) - 2,8 (quite good). (Table 8).

Lack availability of water has such a constraint felt by the farmer group of Gunungpati II. This is due to its location in upper Gunungpati (mountainous area). Therefore, the availability of water is limited. So far, farmers have used generators to take water from wells. In dry season, the condition is worse. Water is so limited that durian crops are highly vulnerable to death. 
Table 8:

Availability of Facility and Supporting Activities Leading Commodity in the District of Gunungpati

\begin{tabular}{clcccc}
\hline No & \multicolumn{1}{c}{ CRITERIA } & Durian & Longan & Rambutan & Water apple \\
\hline 1 & Physical Infrastructure & 2,4 & 2,7 & 2,3 & 2,3 \\
2 & Information Infrastructure & 2,5 & 2,5 & 2,5 & 2,8 \\
3 & Knowledge Infrastructure & 2,1 & 2,1 & 2,0 & 2,3 \\
4 & Technology Infrastructue & 1,9 & 2,1 & 1,8 & 2,1 \\
5 & Production service (KUD/KUB) & 1,5 & 1,5 & 1,5 & 1,4 \\
6 & Service for crop protection (Ag- & 2,5 & 2,4 & 2,6 & 2,4 \\
& ricultural Office) & & & & \\
7 & Counselling & 2,5 & 2,5 & 2,6 & 2,4 \\
& Averages & $\mathbf{2 , 2 4}$ & $\mathbf{2 , 3 0}$ & $\mathbf{2 , 2 0}$ & $\mathbf{2 , 1 0}$ \\
\hline
\end{tabular}

Source: Primary Data

Facilities and infrastructure are the responsibility of the government. In order to be an agricultural city of tourism, infrastructures are fundamental. Take, for example, roads and irrigation channels. Roads like in China and Thailand as access to reach the location are the prerequisite if Gunungpati would like to be the center of horticultural commodities. Today, Gunungpati is preparing to develop such center. Since 2010, budget from APBN has been prepared to build megaproject of Central Java, i.e. Jatibarang Lake. This lake is expected to overcome lack water that has always been the problem in cultivating horticultural crops.

Ideally, there should be a small lake in every $20 \mathrm{Ha}$ of land. The lake is the responsibility of the government. Generally, asmall lake of $800 \mathrm{~m}^{2}$ is built every $1 \mathrm{Ha}$. The lake will be used to water an area of $20 \mathrm{Ha}$.

\section{Strategies for Developing Center of Commodities}

Strategies for developing center of commodities in the District of Gunungpati should refer to environmental analysis. The main problem is the availability of a commodity and its continuity. By utilizing the potential possessed by the area, some strategies of development can be formulated as follows: Firstly, Identifying seeds for superior commodity per area and doing the nurs- ery. This strategy is urgent since each area has different characteristics of land (type, fertility, water availability, and agriclimate). Secondly, Promoting Gunungpati Durian Agro expo from the last week of December untill the end of first week of January, particularly for Gunungpati and community. This activity is crucial. For centers, this event can function for marketing and identifying local durian having high quality of taste and appearance. After that, high quality durians can be grown for seeding. As a result, quality and quantity of durian will improve.

Third, Building educational tour located in the tourism area. In Shanghai, China, tourism objects cooperate with universities for its educational tour. Therefore, students of kindergarten, SD (Elementary School), and SMP (Junior High School) can learn there. They can learn how to plant, harvest, and utilize the produce. Cooperation between manager of the tourism object and officials is necessary because the place needs some area of land for planting, harvesting, and preparing products which are ready to eat from the commodity.

Fourth, Making innovation by means of research and development. Innovation in developing product or process. Innovation is needed for differentiation of product from commodities that had been 
produced by the center especially for those having low economical value like rambutan. Rambutan can be made to be processed food like rambutan jam, rambutan pickle, rambutan syrup, and so on. This should become priority because if it works well, this will help to run industries aroundAgricultural Tourism of Gunungpati. Fifth, For long term strategy, internal information technology in the form of system should be developed. This technology is needed in order to enable collection and update of product data as well as other information related to horticulture. The system should be accessible to all members.

\section{Conclusion}

The City of Semarang has mountainous land contour which is distinct in characteristics from one area to another. Based on basic sectoral analysis, it is found that there are 7 fruit commodities having comparative advantage (LQ>1) from 2009 to 2011, namely durian, rambutan, longan, mangosteen, soursop, banana and jackfruit. There are 11 commodities having competitive advantage (positive shift share value) namely rambutan, durian, longan, mango, banana, mangosteen, duku, breadfruit, grape fruit (jeruk besar), avocado, and star fruit. There are only five commodities that can compete with other commodities in the city,they are rambutan, durian, mangosteen, longan, and banana.

Based on scoring analysis and capacity assessment through participative fo- cus group discussion (FGD), leading commodities in the District of Gunungpati are durian, longan, water apple, and rambutan. Although avocado and Jambu Kristal are also cultivated, but the cultivation is limited in a few locations only. The development of the commodity needs improvement on its postharvest time and marketing. This is revealed from result of scoring analysis showing that the average score of the indicator ranging between 1.01 (very bad) and 2.61 (quite good) only.

Today, strategies for developing center of commodities are directed to keep and maintain the continuity of stock. Organizing Gunungpati Durian Expo is one of ways to find local durian varieties that can be developed in the nursery of durian.

By considering results obtained from estimation analysis, and related to the determination of the District of Gunungpati as the agricultural tourism area, there are things to consider by the Government of Semarang City. Firstly, determination of an area to be the center of commodity should be openly informed and socialized particularly to the groups of farmers. This is important in order to minimize conflict among them. Secondly, the government and officials should socialize the program comprehensively. There should be real actions like building or improving infrastructure and other supporting facilities in all parts of the tourism area so as to ease horticultural industrialists or entrepreneurs in running their business.

\section{REFERENCES}

Agriculture Office of Semarang City, http://dinpertantph.jatengprov.go.id/hortifest3.pdf accessed on 28 February 2013, 11.15 west Indonesia time.

Arifin, B. (2013), “Governansi dan Kewibawaan Kebijakan Pangan," Seminar Paper Konvensi Kampus IX dan Temu Tahunan XV Forum Rektor Indonesia (FRI), Islamic University of Sultan Agung, Semarang.

Central Bureau of Statistics (2012), Agricultural Statistic 2012, Badan Pusat Statistik, Semarang.

Central Bureau of Statistics (2012), Semarang City in Numbers, Badan Pusat Statistik, Semarang. 
Directorate General of Horticulutre (2012), www.hortikultura.deptan.go.id, Departemen Pertanian accessed on 28 February 2013, 12:00 west Indonesia time.

Directorate General of Indonesian Agriculture (2009), http://hortikultura.deptan.go.id/sites/, Departemen Pertanian, Accessed on 13 February 2013, 12:15 west Indonesia time.

Hagi, S.H. and E. Tety (2013), “Analisis Daya Saing Ekspor Minyak Sawit Di Indonesia dan Malaysia di Pasar Internasional," Jurnal Pendidikan Ekonomi dan Bisnis, 4(3), 180-191.

Irawan, B. (2003), "Agribisnis Hortikultura: Peluang dan Tantangan Dalam Era Perdagangan Bebas," Socio-Economic of Agriculture and Agribusiness (SOCA) Journal, 3(2), 1-22.

Margunani, M., E. Soesilowati and D.M. Nihayah (2012), "Pemetaan Potensi Ekonomi Tanaman Hortikultur Sebagai Komoditas Unggulan Di Gunungpati, Kota Semarang,” Research Report, Universitas Negeri Semarang.

Mather, C. (1999), "Agro-commodity Chains, Market Power and Territory: Re-regulating South African Citrus Exports in the 1990s," Geoforum, 30(1), 61-70.

Murwatiningsih, M. (2009), “Analisis Pengaruh Persepsi Kualitas Jasa Layanan Pariwisata Terhadap Keputusan Kunjungan Wisatawan Di Kota Semarang," Research Report, Universitas Negeri Semarang.

Muslim, C. (2006), “Analisis Daya Saing Produk Ekspor Agroindustri Komoditas Berbasis Kelapa di Indonesia," ICASEPS Working Paper, 87, Pusat Analisis Sosial Ekonomi dan Kebijakan Pertanian, Badan Penelitian \& Pengembangan Pertanian, Departemen Pertanian.

Nihayah, D.H. (2011), "Ekspor Produk Unggulan Sektor Agroindustri Menuju Free Trade Area: Kinerja dan Proyeksi," Research Report, Universitas Negeri Semarang.

Nihayah, D.H. (2012), "Strategi Pengembangan Agrobisnis Tanaman Buah Untuk Mendukung Percepatan Gunungpati Sebagai Kawasan Agrowisata di Kota Semarang,"Prosiding, ISBN 978-602-17035-0-5, Department of Economics Development, Universitas Negeri Semarang.

Patrick, I. (2004), Contract Farming in Indonesia:Smallholders and AgribusinessWorking Together, Australian Centre for International Agricultural Research, Canberra.

Prajanti, S.D.W., and W. Waridin (2010), "Model Penguatan Kapasitas Kelembagaan Penyuluh Pertanian Dalam Meningkatkan Kinerja Usaha Tani Melalui Transaction Cost: Studi Empiris Di Jawa Tengah,” Jurnal Ekonomi Pembangunan, 2(1), 13-29.

Saptana, E.A., K.D. Saktyanu, S. Wahyuningsih and V. Darwis (2004), "Integrasi Kelembagaan Forum KASS dan Program Agropolitan Dalam Rangka Pengembangan Agribisnis Sayuran Sumatera," Analisis Kebijakan Pertanian, 2(3), 257-276.

Suprihatini, R. (2005), “Daya Saing Ekspor Teh Indonesia Di Pasar Teh Dunia,” Jurnal Agro Ekonomi, 23(1), 1-29.

Watanabe, M., N. Jini, and M. Kurihara (2009), "Is the Development of the Agroprocessing Industry Pro-poor?: The Case of Thailand," Journal of Asian Economics, 20(4), 443-455. 